\title{
An investigation on fire effects within xeric sage grouse brood habitat
}

\author{
RICHARD A. FISCHER, KERRY P. REESE, AND JOHN W. CONNELLY
}

\begin{abstract}
Authors are former research assistant and associate professor, Department of Fish and Wildlife Resources, University of Idaho, Moscow, Ida., 83844; and Principal Wildlife Biologist, Idaho Department of Fish and Game, 1345 Barton Rd., Pocatello, Ida., 83205
\end{abstract}

\begin{abstract}
We investigated the short-term influence of fire on xeric sage grouse (Centrocercus urophasianus) brood habitat in southeastern Idaho from 1990-92. A prescribed fire in 1989 removed Wyoming big sagebrush (Artemisia tridentata wyomingensis Nutt.)/threetip sagebrush (A. tripartita Rydb.) canopy cover from approximately $57 \%$ of a 5,800 -ha area, potentially influencing brood-rearing habitat. Although the fire created a mosaic of sagebrush areas interspersed with open areas having abundant grasses and forbs, the relative abundance of males, females, and broods on survey routes in burned and unburned habitat were similar. Cover of forbs important in sage grouse summer diets was similar in burned and unburned habitat. However, the abundance of Hymenoptera, an insect Order important in sage grouse diets, was significantly lower in burned habitat the second and third years postburn. Our research did not support the contention that fire may enhance sage grouse brood-rearing habitat.
\end{abstract}

Key Words: big sagebrush, Centrocercus urophasianus, insects.

Knowledge of the relationship between bird species and their food resources is a critical component of avian ecology (Raley and Anderson 1990). Invertebrates, mainly insects, are consumed in large quantities and provide essential protein in the diets of most young birds, such as waterfowl (Swanson et al. 1985), passerines (Lack 1954), and galliformes (Kobriger 1965, Klebenow and Gray 1968, King 1969). Wyoming big sagebrush (Artemisia tridentata wyomingensis Nutt.) communities have a diverse insect fauna (Homing and Barr 1970, Stafford 1983) that provides an important food source for many vertebrates (Gleason 1978, Halford 1981). High protein foods such as forbs and insects in these communities are important in sage grouse chick diets

\footnotetext{
Funding was provided by the Idaho Department of Fish and Game (IDFG) through the University of Idaho. Logistical support was provided by the U.S. Bureau of Land Managment. This is a contribution from Idaho Federal Aid in Wildlife Restoration Project W-160-R and Contribution 763 of the University of Idaho College of Forestry, Wildlife and Range Experiment Station.

We gratefully acknowledge R. Bradish, A.W. Farris, M.B. Fischer, J.F Kennedy, M.A. Sands, and J.W. Snyder, for their assistance in data collection. W. Newton, R.K. Steinhorst, and C. Williams provided statistical advice.

Present address of senior author: U.S. Army Corps of Engineer Waterways Experiment Station, Attn: CEWES-EN-S, 3909 Halls Ferry Rd., Vicksburg, Miss. 39180 .

Manuscript accepted 29 July 1995.
}

(Klebenow and Gray 1968, Peterson 1970), especially during the first 3 weeks after hatching (Johnson and Boyce 1990).

Sagebrush removal on western rangelands is a common practice for increasing forage availability for livestock. Currently, prescribed fire is a popular and cost-effective method of sagebrush removal (Frandsen 1985, Bunting et al. 1987). However, little is known about how various methods of habitat manipulation affect important foods of sage grouse chicks. Sagebrush treatment projects (e.g., herbicide application) that reduce the abundance and diversity of forbs are detrimental to sage grouse brood habitat (Klebenow 1970). Xeric sagebrush habitats $(\leq 25$ $\mathrm{cm}$ of annual precipitation), usually dominated by Wyoming big sagebrush, typically have relatively low forb abundance compared to other sagebrush habitats (Wright et al. 1979, Clifton 1981, Bunting et al. 1987). Thus, insects as a source of protein in sage grouse chick diets may have greater importance in xeric sagebrush habitats than in more mesic habitats. Reduced insect abundance through pesticide application has been implicated in lowered chick survival in several gallinaceous bird species (Godfrey 1975, Warner et al. 1984, Potts 1986). Johnson and Boyce (1990) evaluated the influence of insect reductions on survival of captive sage grouse chicks, and quantity of insects in the diets was positively correlated with growth and survival.

Klebenow (1972) and Gates (1983) suggested that fire may benefit sage grouse brood habitat if the burn produces a mosaic of sagebrush cover interspersed with open areas having increased forb production. However, the impacts of fire on sage grouse foods, especially insects, have not been addressed. Objectives of this study were to (1) examinc relative use of burned ungrazed habitat and unburned grazed habitat by sage grouse following a prescribed fire, and (2) measure summer forb and insect abundance in burned and unburned sage grouse habitat as an index to food abundance.

\section{Methods}

\section{Study Location and Burning Treatments}

From 1990 to 1992, we conducted research on a 20,000-ha portion of the 240,867-ha Big Desert, in Blaine and Butte counties on the Upper Snake River Plain, southeastern Idaho $\left(43^{\circ} 24^{\prime} \mathrm{N}\right.$, $113^{\circ} 07^{\prime} \mathrm{W}$ ). The topography consisted of flat to gently undulating terrain with an interspersion of exposed silicic and basaltic volcanic outcrops and craters. Median precipitation on the Big Desert during the study $(16.5 \mathrm{~cm} ; 1990-92)$, measured $25 \mathrm{~km}$ 
northwest of the study area in similar habitat, was below the long-term median (24.0 cm; 1956-86 [data from Agricultural Engineering Dept., Univ. Idaho]). Peak precipitation typically occurred from April through June, although there was considerable seasonal and annual variation. Elevations ranged from 1,536 $\mathrm{m}$ to $2,304 \mathrm{~m}$. Hironaka et al. (1983) classified the Big Desert as a Wyoming big sagebrush/bluebunch wheatgrass (Agropyron spicatum Scribn. \& Smith) habitat type; threetip sagebrush (A. tripartita Rydb.), rabbitbrush (Chrysothamnus spp. Nutt.), Sandberg bluegrass (Poa sandbergii Vasey), and bottlebrush squirreltail (Sitanion hystrix Nutt.) were abundant. The Big Desert sagebrush ecosystem provides important sage grouse breeding, nesting, brood-rearing, and wintering habitat (Connelly et al. 1988, Wakkinen 1990, Robertson 1991). Sage grouse on the study area used contiguous areas for wintering and breeding, but migrated as far as $85 \mathrm{~km}$ to summering areas (Wakkinen 1990, Fischer 1994).

During late-summer 1989, the Bureau of Land Management burned approximately 5,800 ha of the northern portion of the study area. Vegetation was removed from $57 \%$ of this total area, resulting in a mosaic of bumed and unburned vegetation (J. W. Connelly, Idaho Dept. of Fish and Game, unpubl. data). Another site of approximately equal size was $6 \mathrm{~km}$ south of the burned area, and was not altered during the study. Mean preburn sagebrush canopy cover was $19.8 \%$ and grass cover was $6.4 \%$ (J. W. Connelly, Idaho Dept. Fish and Game, unpubl. data). There was a potentially confounding influence of differential grazing history on these 2 areas. All portions of the study area were grazed by cattle throughout the study except for the burned area, which was ungrazed from fall 1988 to fall 1991. Livestock exclusion for at least 2 years following prescribed burns is a suggested practice in big sagebrush communities (Wright et al. 1979). Wakkinen (1990) and Robertson (1991) provided detailed descriptions of the Big Desert study area.

\section{Bird Censuses}

We counted adult sage grouse and broods weekly on two, 20 to $25 \mathrm{~km}$ routes through unburned habitat and $1,21-\mathrm{km}$ route through burned habitat, from mid-May through mid-August, 1990 to 1992 . The census route through burned habitat included both burned and unburned areas within the vegetation mosaic. Routes were conducted during the evening with either a truck or all-terrain vehicle. All adult sage grouse on census routes were recorded by sex, and brood sizes were noted. We converted observations for each route to relative abundance (number per $\mathrm{km}$ ) of males, females, and broods, to standardize for different route distances. Data were available from identical preburn census routes conducted during each July, 1987 to 1989 (J. W. Connelly, Idaho Dept. of Fish and Game, unpubl. data). Relatively few grouse were observed on July postburn census, producing many "zero" observations. Also, the proportion of grouse remaining in the study area during summer varied with precipitation and plant moisture content (Fischer 1994). These 2 factors precluded a statistical comparison of pre- and postburn July brood data. However, means for each variable during July, 1987 to 1992, were plotted for a visual comparison.

\section{Food Abundance \\ Insects}

Concurrent with brood censuses, we sampled arthropods using 3 methods. We used a $0.38-\mathrm{m}$ diameter sweep net (for grass and forb-dwelling arthropods) and $0.71-\times 0.71-\mathrm{m}$ beating sheet (for shrub-dwelling arthropods) to sample arthropods at brood locations along 1990 census routes. When a brood was observed along a census route, we marked the activity center, and returned to the location at approximately the same time the next day to collect arthropods. We placed the beating sheet under the closest sagebrush shrub in each cardinal direction, and beat all branches within $0.5 \mathrm{~m}$ of the ground to remove any arthropods. We then used the sweep net to make 10 sweeps through grasses and forbs in each cardinal direction from the activity center. Samples from each transect (arthropods, shrub detritus, and vegetation) were sealed in separate, air-tight bags. To determine potential differences in insect abundance between brood and non-brood locations, we sampled 6 random sites ( 3 burned, 3 unburned) each week (May through July) within the study area, using identical sampling methods. Only 7 broods were observed during all 1991 and 1992 census routes, which precluded sufficient arthropod sampling at brood locations during these years.

We also employed a weekly pitfall trapping method at 8 random locations ( 4 burned, 4 unburned) within the study area, May through July, 1990 to 1992 , to assess differences in grounddwelling insect abundance between burned and unburned sage grouse habitat. However, to reduce the possibility of bias associated with reduced arthropod populations by repeated sampling at the same sites, we chose 2 additional sub-sites near each of the 8 initial random sites by walking in a randomly generated direction and distance $(\leq 100 \mathrm{~m}$ ) from the initial site. We then established a $4 \times 4$ test tube pitfall grid with line intersections at $2-\mathrm{m}$ intervals at each of the 24 sites, and sampled each site every third week ( 8 sub-sites per week). Test tubes were filled with a 1:1 solution of ethylene glycol and water, then buried flush with the ground. We opened traps in the morning, and closed and removed them the evening of the following day. Samples from all tubes at each grid were combined and stored in closed vials filled with a $70 \%$ ethanol solution for 1 to 3 months before analysis. Arthropod sampling techniques follow Cooper and Whitmore (1990).

In the laboratory, insects (Class Insecta) were separated from shrub detritus, vegetation, and other arthropods with the aid of magnifying glasses. Because we were specifically interested in the effects of fire on sage grouse foods, we separated insects into the 3 major Orders [Hymenoptera (ants), Coleoptera (beetles), and Orthoptera (grasshoppers)] known to be important in juvenile sage grouse diets (Klebenow and Gray 1968, Peterson 1970). Numbers of individuals in each sample were then counted.

\section{Forbs}

Twenty-two 50 -m permanent transects were established 2 months before the 1989 fire at random locations in $(n=12)$ and adjacent to $(n=10)$ the area to be bumed. Vegetation characteristics were measured on all transects in late June/early July, 1989 to 1993 (K. P. Reese, unpubl. data). Thus, there was 1 year of preburn and 4 years of postburn vegetation data on the burned and unburned habitat. Along each transect, forb cover was sampled using $0.2 \times 0.5-\mathrm{m}$ plots (Daubenmire 1959) spaced at $1-\mathrm{m}$ intervals. Forbs were categorized as major forbs, those species known to be important in sage grouse diets (common dandelion [Taraxacum officinale Weber], milkvetch [Astragalus spp.], common salsify [Tragapogon spp.], sego lily [Calochortus spp.], common yarrow [Achillea spp.], prickly lettuce [Lactuca spp.], lupine [Lupinus spp.], hawksbeard [Crepis spp.]) (Klebenow and Gray 1968, Peterson 1970, Wallestad et al. 1975), and minor forbs, those species not known to be important food components. 


\section{Statistical Analysis}

We used either SAS (SAS Inst., Inc. 1988) or STATISTIX (Analytical Software, Inc., St. Paul, MN) to analyze data, and considered differences significant if $P \leq 0.05$. All variables were also tested for normality using a Kolmogorov-Smirnov D-statistic (Stephens 1974), and appropriate transformations were used to approximate the normal distribution before statistical tests (Zar 1984). To assess differences between burned and unburned habitat, we used a repeated measures analysis of variance (ANOVA; PROC GLM) with orthogonal contrasts to compare potential differences in relative abundance of males, females, and broods between areas after the fire, and potential differences in major and minor forb cover before and after fire. We used a mixedmodel ANOVA to compare insect abundance between brood and non-brood locations (sweep net/beating sheet), and between burned and unburned locations (pitfalls). Because few Orthoptera were captured with any collection method, we used a binomial test on frequency of nonzero data to determine if Orthoptera were captured more or less frequently in either area, and a $t$-test or Mann-Whitney- $U$ test (depending on normality) on nonzero data to detect differences in abundance among samples in which Orthoptera were captured. We tested all main effects and interactions using appropriate error terms.

\section{Results}

\section{Bird Censuses}

From 1987 to 1992, the relative abundance of broods declined in burned and unburned habitat, except for 1990. Visual comparisons of July pre- and postburn data revealed no large differences in relative abundance of males, females, and broods between areas. After the fire, the relative abundance of males $(\mathrm{F}=2.91, P$ $=0.20)$, females $(\mathrm{F}=3.49, P=0.15)$, and broods $(\mathrm{F}=1.26, P=$ 0.25 ) observed on routes was also similar between burned and unburned habitat (Table 1).

\section{Food Abundance \\ Insects}

The abundance of Hymenoptera at 1990 brood activity areas ( $n$ $=33$ ) was higher than at non-brood locations $(n=74)$ using both the sweep net $(x=7.03$ vs. $x=3.51, P=0.019)$ and beating sheet $(x=12.90$ vs. $x=2.93, P=0.022)$. Orthoptera were captured more frequently (binomial test; $P=0.024$ ) at brood activity areas than non-brood sites with a sweep net, but there were no differences in abundance between burned and unburned areas at sites where Orthoptera were captured (Mann-Whitney- $U$ test; $P=$ 0.805). No difference in Coleoptera abundance between brood and non-brood locations was detected, however these 2 techniques are not effective in capturing ground-dwelling arthropods such as most beetle species. Relative abundance of Hymenoptera and Coleoptera captured in pitfall traps was similar between burned and unburned areas in 1990, the first year following the fire $\left(\mathrm{F}_{1,91}=0.01, P=0.920 ; \mathrm{F}_{1,89}=0.58, P=0.450\right.$, respectively). However, there were significantly fewer Hymenoptera in burned habitat the second $(F=9.20, P=0.003)$ and third $(F=$ $17.11, P=0.0001$ ) years postburn (Table 2). There were no differences in Orthoptera capture frequency or abundance in 1991 or 1992 pitfall traps (Table 2). Coleoptera abundance was similar between burned and unburned areas during all 3 postburn years. Hymenoptera abundance was similar among months in burned (ANOVA; $F_{2,139}=0.83, P=0.437$ ) and unburned areas $\left(F_{2,136}=\right.$ $0.13, P=0.875$ ), as was frequency of Orthoptera captures.

\section{Forbs}

There was variation in annual major and minor forb cover, however, there were no significant differences in either variable $\left(\mathrm{F}_{1,9}=1.55, P=0.216 ; \mathrm{F}_{1,9}=0.37, P=0.544\right.$, respectively) before or after the fire (Fig. 1).

\section{Discussion}

Prescribed fire created a patchy mosaic of sagebrush interspersed with open areas containing forbs and grasses (K.P. Reese, Univ. of Idaho, unpub. data). Bunting et al. (1987) found that forb cover in Wyoming big sagebrush habitats is typically low, and these xeric habitats have little potential for forb increase following fire, relative to the more mesic sagebrush habitats. Our forb cover data before and after fire were consistent with these findings. Martin (1990) found a significant increase in forbs the first 2 years following fire in Eastern Idaho, but his study was conducted in a more mesic area (i.e., $30-50 \mathrm{~cm}$ annual precipitation) dominated by threetip sagebrush and mountain big sagebrush (A. t. vaseyana Nutt.). Hymenopteran abundance was lower within the burned portion of our study area, suggesting that fire negatively influenced insects important in sage grouse diets.

Table 1. Number of sage grouse broods; distance travelled; and relative abundance of broods, females, and males on survey routes in burned and unburned habitat, Big Desert, southeastern Idaho (1987 to 1992).

\begin{tabular}{|c|c|c|c|c|c|c|c|c|c|c|}
\hline \multirow{2}{*}{ Year } & \multirow{2}{*}{\multicolumn{2}{|c|}{ Number of Broods }} & \multirow{2}{*}{\multicolumn{2}{|c|}{ Distance travelled 1}} & \multicolumn{6}{|c|}{ Relative Abundance } \\
\hline & & & & & \multicolumn{2}{|c|}{ Broods } & \multicolumn{2}{|c|}{ Females } & \multicolumn{2}{|c|}{ Males } \\
\hline 1987 & 43 & 13 & 688 & 614 & 63 & 21 & 58 & 125 & 18 & 44 \\
\hline 1988 & 10 & 3 & 494 & 329 & 20 & 91 & 57 & 27 & 2 & 3 \\
\hline 1989 & 6 & 2 & 317 & 209 & 19 & 100 & 181 & 96 & 17 & 38 \\
\hline \multicolumn{11}{|c|}{ Postbum (May through July) } \\
\hline 1990 & 22 & 6 & 666 & 449 & 33 & 13 & 14 & 5 & 14 & 11 \\
\hline 1991 & 4 & 1 & 880 & 579 & 5 & 2 & 28 & 4 & 10 & 0 \\
\hline 1992 & 2 & 0 & 777 & 516 & 3 & 0 & 0 & 0 & 0 & 0 \\
\hline
\end{tabular}

1 Total distance travelled each year 
Table 2. Comparison of insect abundance from pitfall trap samples at burned versus unburned locations, Big Desert, southeastern Idaho (Mlay to July, 1990 to 1992).

\begin{tabular}{|c|c|c|c|c|c|c|}
\hline \multirow[b]{3}{*}{ Order } & \multicolumn{6}{|c|}{ Year } \\
\hline & \multicolumn{2}{|c|}{$1990(n=95)$} & \multicolumn{2}{|c|}{$1991(n=85)$} & \multicolumn{2}{|c|}{$1992(n=101)$} \\
\hline & Raw data ${ }^{a}$ & $\log ^{b}$ & Raw data & $\log$ & Raw data & Log \\
\hline \multicolumn{7}{|c|}{ Hymenoptera } \\
\hline Bumed & 241.0 & $2.24 a$ & 191.7 & $2.20 \mathrm{a}$ & 86.1 & $1.8 \mathrm{a}$ \\
\hline Unburned & 261.7 & $2.23 a$ & 289.8 & $2.38 b$ & 151.7 & $2.1 \mathrm{~b}$ \\
\hline \multicolumn{7}{|l|}{ Coleoptera } \\
\hline Burned & 3.8 & $0.56 \mathrm{a}$ & 2.7 & $0.47 \mathrm{a}$ & 2.9 & $0.5 \mathrm{a}$ \\
\hline Unbumed & 3.9 & $0.50 \mathrm{a}$ & 2.4 & $0.44 a$ & 2.0 & $0.4 \mathrm{a}$ \\
\hline \multicolumn{7}{|c|}{ Orthoptera $^{\mathrm{c}}$} \\
\hline Bumed & $-d$ & - & $1.8^{\mathrm{a}}$ & - & $1.3^{3}$ & - \\
\hline Unburned & 一 & - & $1.5^{\mathrm{a}}$ & - & $1.7^{\mathrm{a}}$ & - \\
\hline
\end{tabular}

${ }^{3}$ Numbers indicate mean number of insects captured in pitfall grids per week.

b Statistical comparisons wcre conducted on log-transformed data.A pair of means in a column followed by a different letter is significantly different $(P<0.05)$.

c Few Orthoptera were captured in piffall traps.A binomial test on frequency of nonzero data was not significant in 199 lor 1992.Means are reported for a t-test on nonzero data.

Data not collected

Drought probably also influenced both forb and insect populations on our study area, given the low precipitation (31.3\% below long-term median) during the study. Because there was no positive response (i.e., increase in relative abundance) of sage grouse to burned habitat following the fire, our results from a xeric environment did not support Klebenow's (1972) and Gates' (1983) speculation that fire may benefit sage grouse brood habitat. However, our data were collected under a pseudoreplicated design ( 1 control, 1 treatment); true replication in this study was not possible. We investigated a migratory population that collectively ranges over several thousand square miles during the year. Additional prescribed fires, regardless of their size, within the range of this population would not have been true replicates, but rather sub-samples. Additional burns at the scale used in this study also would have occurred in different precipitation zones, sagebrush habitat types, or sage grouse populations. Thus, additional research is needed to fully understand the influence of fire on sage grouse brood-rearing habitat, especially in other sagebrush habitat types and under conditions not encountered in the present study.

Relatively few Orthoptera were captured in our study area (brood or non-brood sites) using any of the collection methods, suggesting low availability for Big Desert sage grouse. Bock and Bock (1991) found reduced Orthoptera abundance 1 year following fire in an Arizona grassland, but no difference 3 years postburn. Coleoptera abundance in our study area was also low in burned and unburned habitat and appeared unaffected by fire. However, Rickard (1970) investigated Coleoptera abundance in burned and unburned sagebrush habitat and found more beetles in unburned habitat. Lower abundance and biomass of Hymenoptera in the burn the second and third years postburn suggested that fire negatively influenced insects important in juvenile sage grouse diets for several years following fire. We did not sample insect abundance prior to the fire, thus we cannot attribute differences in abundance between areas to fire. However, because insect abundance was similar between areas the first year following the fire, and Hymenoptera abundance significantly decreased with time, a difference between burned and unburned habitat was indicated.

Timing of breeding activities may correspond to temporal abundance of food resources so that chicks hatch when insects are most abundant (Lack 1954, Poulin et al. 1992). Timing of sage grouse hatching may also coincide with peak insect abundance during the spring. We found that Coleoptera abundance was highest in late May/early June and declined steadily over the summer. Hymenoptera and Orthoptera abundance remained fairly stable over this same period. In Idaho, Stafford (1983) sampled summer Coleoptera abundance and found highest numbers occurring during the first 2 weeks of June, followed by a decline in late summer. Peak hatching of sage grouse nests in our study was late May/early June (Wakkinen 1990), which would correspond with peak abundance of important insects. Dalke et al. (1960) also found peak hatch during late May/early June in eastern Idaho. Other important factors that probably influenced timing of sage grouse nesting in xeric environments include renesting opportunities (Connelly et al. 1993), snowmelt, and plant-phenology.

\section{Conclusions}

The results of our research indicated that the short-term effects of prescribed fire in a xeric environment did not enhance broodrearing habitat, and may have been detrimental to Hymenoptera which are important in sage grouse diets. Prescribed fire can variably affect sagebrush-grass habitats depending on the intensity, duration, location, shape, and extent of the fire (Bendell 1974,

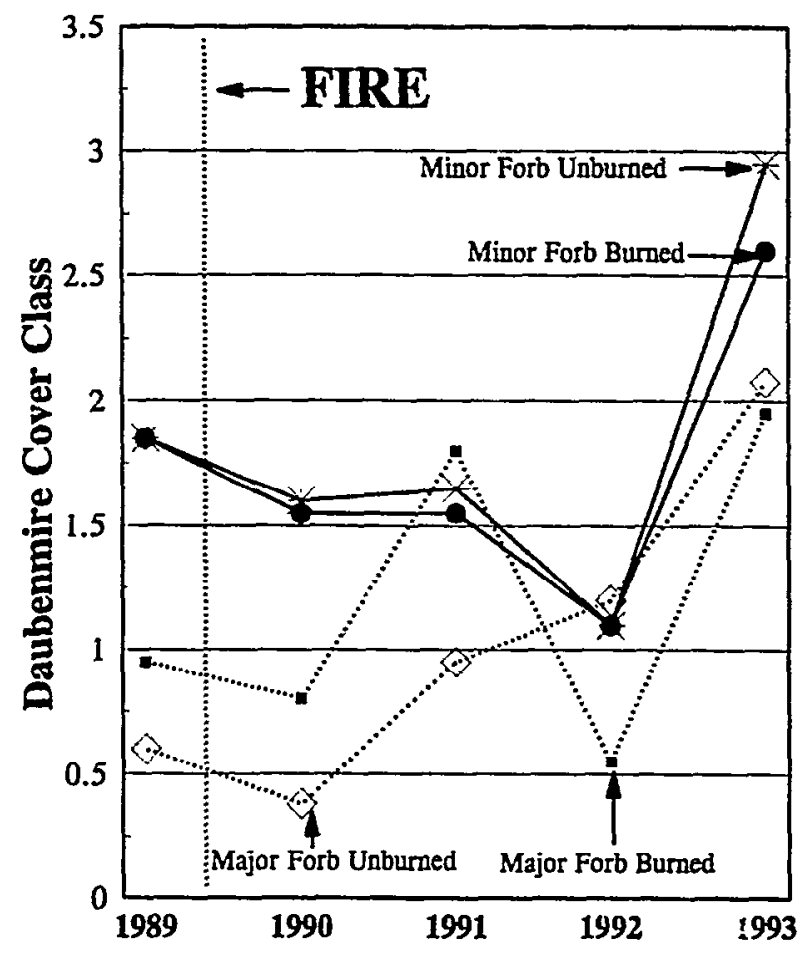

Fig. 1. Abundance of major forbs and minor forbs, expressed in Daubenmire classes $(1=0-5 \%$ cover; $2=5-25 \%$ cover; $3=25-$ $50 \%$ cover), measured on permanent transects in burned and unburned sage grouse habitat on the Big Desert, southeastern Idaho, 1990 to 1993 . The burn occurred after the 1989 data were collected. 
Sapsis and Kauttmann 1991), and environmental conditions, species composition, and available fuel (Winward 1985). Caution is needed when using fire in xeric sagebrush habitats (i.e., $\leq 25$ $\mathrm{cm}$ annual precipitation) as a management tool for sage grouse brood habitat because forb cover and abundance may not be enhanced by burning. Because the response of sagebrush/grass vegetation to fire is highly dependent on geographic area and sagebrush subspecies (Bunting et al. 1987), forbs and insect populations in more mesic sage grouse habitats may respond differently to fire.

\section{Literature Cited}

Bendell, J.F. 1974. Effects of fire on birds and mammals, pp. 73-138. In: T. T.Kozlowski and C. E. Ahlgren (eds.), Fire and ecosystems. Academic Press, N.Y.

Bock, C.E. and J.H. Bock. 1991. Response of grasshoppers (Orthoptera: Acrididae) to wildfire in a southeastern Arizona grassland. Amer. Midl. Natur. 125:162-167.

Bunting, S.C., B.M. Kilgore, and C.L. Bushey. 1987. Guidelines for prescribed burning in sagebrush-grass rangelands in the Northern Great Basin. USDA Forest Service, Intermountain Research Station, Gen. Tech. Rep. INT-231. Ogden, Utah.

Clifton, N.A. 1981. Response of a prescribed fire in a Wyoming Big Sagebrush/Bluebunch Wheatgrass habitat type. M.S. Thesis, Univ. of Idaho. Moscow, Ida.

Connelly, J.W., H.W. Browers, and R.J. Gates. 1988. Seasonal movements of sage grouse in southeastern Idaho. J. Wildl. Manage. 52:116-122.

Connelly, J.W., R.A. Fischer, A.D. Apa, K.P. Reese, and W.L. Wakkinen. 1993. Renesting of sage grouse in southeastern Idaho. Condor 95:1041-1043.

Cooper, R.J. and R.C. Whitmore. 1990. Arthropod sampling methods in omithology. Studies in Avian Biol. 13:29-37.

Dalke, P.D., D.B. Pyrah, D.C. Stanton, J.E. Crawford, and E.F. Schlatterer. 1960. Seasonal movements and breeding behavior of sage grouse in Idaho. Trans. N.Amer. WildI. Conf. 25:396-406.

Daubenmire, R.F. 1959. A canopy-coverage method of vegetation analysis. Northwest Sci. 33:43-64.

Fischer, R.A. 1994. The effects of prescribed fire on the ecology of migratory sage grouse in southeastern Idaho. Ph.D. Diss., Univ. of Idaho, Moscow, Ida.

Frandsen, O.A. 1985. Fire as a management tool in Southeast Idaho, pp. 85-87. In: K. Sanders and J. Durham (eds.), Rangeland fire effects: Proceedings of a symposium. Boise, Ida.

Gates, J.G. 1983. Sage grouse, lagomorph and pronghom use of a sagebrush-grassland burn site on the Idaho National Engineering Laboratory. M.S. Thesis, Mont. State Univ. Bozeman, Mont.

Gleason, R.S. 1978. Aspects of the breeding biology of burrowing owls in southeastem Idaho. M.S. Thesis, Univ. of Idaho. Moscow, Ida.

Godfrey, G.A. 1975. Home range characteristics of ruffed grouse broods in Minnesota. J. Wildl. Manage. 39:287-298.

Halford, D.K. 1981. Repopulation and food habits of Peromyscus maniculatus on a burned sagebrush desert in southeast Idaho. Northwest Sci. 55:44-49.

Hironaka, M., M.A. Fosberg, and A.H. Winward. 1983. Sagebrushgrass habitat types in southern Idaho. University of Idaho, Forestry, Wildlife, and Range Exp. Sta. Bull. 35.

Horning, D.S. Jr., and W.F. Barr. 1970. Insects of Craters of the Moon National Monument, Idaho. Univ, of Idaho College of Agr. Misc. Ser. No. 8.

Johnson, G.D. and M.S. Boyce. 1990. Feeding trials with insects in the diet of sage grouse chicks. J. Wildl. Manage. 54:89-91.

King, R.D. 1969. Spring and summer foods of ruffed grouse on Vancouver Island. J. Wildl. Manage. 33:440-442.

Klebenow, D.A. 1970. Sage grouse versus sagebrush control in Idaho. J. Range Manage. 23:396-400.
Klebenow, D.A. 1972. The habitat requirements of sage grouse and the role of fire in management. Proc. Ann. Tall Timbers Fire Ecol. Conf. 12:305-315.

Klebenow, D.A. and G.M. Gray. 1968. Food habits of juvenile sage grouse. J. Range. Manage. 21:80-83.

Kobriger, G.D. 1965. Status, movements, habitats, and foods of prairie grouse on a sandhills refuge. J. Wildl. Manage. 29: 788-800.

Lack, D. 1954. The natural regulation of animal numbers. Oxford University Press, London.

Martin, R.C. 1990. Sage grouse responses to wildfire in spring and summer habitats. M.S. Thesis, Univ. Idaho. Moscow, Ida.

Peterson, J.G. 1970. The food habits and summer distribution of juvenile sage grouse in central Montana. J. Wildl. Manage. 34:147-155.

Potts, G.R. 1986. The partridge. Pesticides, predation and conservation. Collins, London.

Poulin, B., G. Lefebvre, and R. McNeil. 1992. Tropical avian phenology in relation to abundance and exploitation of food resources. Ecology. 73:2295-2309.

Raley, C.M. and S.H. Anderson. 1990. Availability and use of arthropod food resources by Wilson's Warblers and Lincoln's sparrows in southeastern Wyoming. Condor 92:141-150.

Rickard, W.H. 1970. Ground-dwelling beetles in burned and unburned vegetation. J. Range Manage. 23:293-294.

Robertson, M.D. 1991. Winter ecology of migratory sage grouse and associated effects of prescribed fire in southeastern Idaho. M.S. Thesis, Univ. of Idaho. Moscow, Ida.

Sapsis, D.B. and J.B. Kauffman. 1991. Fuel consumption and fire behavior associated with prescribed fires in sagebrush ecosystems. Northwest Sci. 65:173-179.

SAS Institute, Inc. 1988. SAS/STAT User's Guide, Release 6.03 Edition. SAS Institute Inc., Cary, N.C.

Stafford, M.P. 1983. Surface-dwelling Coleoptera inhabiting sagebrush in southeastern Idaho. M.S. Thesis, Univ. of Idaho. Moscow, Ida.

Stephens, M.A. 1974. EDF statistics for goodness of fit and some comparisons. J.Amer. Stat. Assoc. 69:730-737.

Swanson, G.A., M.I. Meyer, and V.A. Adomaitis. 1985. Foods consumed by breeding mallards on wetlands of south-central North Dakota. J. Wildl. Manage. 49:197-203.

Wakkinen, W.L. 1990. Nest site characteristics and spring-summer movements of migratory sage grouse in southeastern Idaho. M.S. Thesis, Univ. of Idaho. Moscow, Ida.

Wallestad, R.O., J.G. Peterson, and R.L. Eng. 1975. Foods of adult sage grouse in central Montana. J. Wildl. Manage. 39:628-630.

Warner, R.E., S.L. Etter, G.B. Joselyn, and J.A. Ellis. 1984. Declining survival of ring-necked pheasant chicks in Illinois agricultural ecosystems. J. Wildl. Manage. 48:82-88.

Winward, A.H. 1985. Fire in the sagebrush-grass ecosystem- the ecological setting, pp. 2-6. In: K. Sanders and J. Durham (eds.), Rangeland fire effects: a symposium; Proceedings. Boise, Ida.

Wright, H.A., L.F. Neuenschwander, and C.M. Britton. 1979. The role and use of fire in sagebrush-grass and pinyon-juniper plant communities: a state-of-the-art review. USDA Forest Ser., Intermountain Forest and Range Exp. Station. Gen. Tech. Rep. INT-58. Ogden, Utah.

Zar, J.H. 1984. Biostatistical Analysis. 2nd ed. Prentice-Hall, Englewood Cliffs, N.J. 